\title{
THE EFFECTIVENESS OF OBSERVE AND REMEMBER GAME TO STUDENTS' VOCABULARY MASTERY
}

\author{
By: \\ Cahyati \\ Sekolah Tinggi Ilmu Tarbiyah Muhammadiyah Tanjung Redeb, East Kalimatan \\ cahyat1991@gmail.com \\ Yuli Puji Astutik \\ Sekolah Tinggi Ilmu Tarbiyah Muhammadiyah Tanjung Redeb, East Kalimatan \\ billie.imoetz@gmail.com \\ Surti Milarisa \\ Muhammadiyah University of Berau, East Kalimatan \\ milarisa78@gmail.com
}

\begin{abstract}
Vocabulary is a fundamental aspect of learning English. It is interconnected to four English skills, speaking, reading, listening, and writing. It is also interrelated to pragmatics and discourse. Without mastering vocabulary, someone would not be able to express oral and written language. Therefore, English teachers need to have good qualifications in teaching vocabulary to make their class more fun and interesting. Besides, they also need to teach the vocabulary in context so that the students will not lose the exact meaning of the vocabulary they have learned which caused misunderstanding during communication. Therefore, this study aimed to analyze the effectiveness of Observe and Remember Game on students' vocabulary mastery. The writers applied some procedures namely pretest, treatment by using Observe and Remember game then conducting the posttest after applying the game. To analyze the data, t-test was applied using using SPSS to get the mean scores. From the result of the statistical calculation, the average score of the pretest was 49.82, the result of the posttest was 68.46 . It increased by $18.64 \%$. It could be summarized that Observe and Remember game was effective on students' vocabulary mastery.
\end{abstract}

Keywords: observe and remember game, vocabulary mastery

INTRODUCTION

Language is a very crucial aspect of human life. It is used as a tool of communication. Brown (2000) argues that language is a system of arbitrary conventionalized vocal, written, or gestural symbols that allows each persons in society to talk each other clearly. Besides, according to Goldstein in Nordquist 
(2006), "Language is a system of communication using sounds or symbols that permits us to share sense, opinion, ideas, and impressions". From both theories, it can be concluded that language is a system of human communication that can be used as a tool to share something in our minds, opinion, ideas, and activities that had already done. Moreover, Astutik (2019) states that Learning English, especially at schools is intended for students to have knowledge and skills as a tool to become members of the globa community.

English has main role in the process of modernization since it has become a bridge of international communication of economy, social, cultural, science, education, business entertainment, and so on. Due to that reason, Indonesian government has decided English as a foreign language to be learned by students in the schools.

According to Harmer (1995), in learning a language, students should master receptive skills (listening and reading) and productive skills (speaking and writing). Besides those skills, students also need to master aspects of English language which consists of grammar, vocabulary, spelling, and pronunciation. Among those aspects of English language, vocabulary is one of the students' learning ways to enrich their ability and understanding of language.

Everyone should realize that they got their language since they were children. They got their language from their parents as their mother tongue, they got it from their friends and also from their environment. When they grow, they 
would get another language from their schools such as English, Japanese, Arabic, etc. They use them as foreign languages.

Hutcison (2004) explains that mastering English is not about the fun or values of understanding language, but it is the way to do international communication and technology and commerce in globalization era. For that reason, English has become very crucial in the process of bridging international communication.

The students from junior high school level to university level had problems to learn English. The reason for such a condition is due to the same process of learning English as a foreign language at the first stage of their life since they were children. Milarisa (2018) states that the children have problems communicating their intention by using English to the interlocutor because they do not have good pronunciation. It can be said that learners have many difficulties with learning because of a lack of vocabulary knowledge and not comprehend enough about the pronunciation of those vocabularies. Each school in Indonesia must prepare the best treatment to the students by providing some qualified or professional teachers and also some great facilities to facilitate the teaching-learning process.

$$
\text { Vocabulary influences }
$$

someone's understanding. Lack of mastering vocabulary, someone will find it difficult in mastering four skills of English including reading, speaking, listening, and also writing. According to Neuman and Dwyer (2009), vocabulary is collection of words that person must 
understand how to do communication successfully; words in speaking and in listening (expressive and receptive vocabularies).

To be able to speak English fluently someone needs at least 20006000 words and it can only be achieved by building vocabulary. Actually, in routine classroom activities, students frequently discover difficulties to build their vocabularies and differentiating verbs, adjectives, adverbs, nouns as part of lexicon building. This is the reason why the writers applied the Observe and Remember Game to create a new style of teaching so that it is expected to be a good way to gain students' understanding of learning vocabulary.

The writers also expected that after conducting this research, it will be useful for some people who need to expand their understanding of building up the vocabulary.

\section{METHODOLOGY}

This research used quantitative research. The research design of this research was quasiexperimental. Muijs (2004) explains that quasi-experimental design refers to approximate as closely as possible the benefits of true experimental designs where the problems mentioned, namely implement a program in a native school setting.

The researchers took quasiexperimental design because the research tried to know the use of the Observe and Remember Game technique had a significant effect on the eleventh-grade students of SMA Muhammadiyah Tanjung Redeb. More specifically, the 
design of this research was the quasi-experimental with a nonequivalent control group design.

This research was conducted from February $07^{\text {th }}$ to March $14^{\text {th }}$, 2019. The research covered several steps namely pretest, treatment, posttest. The population of the study was the eleventh grade of SMA Muhammadiyah Tanjung Redeb. The writers took two samples as their research subject namely XI IPS 1 as experimental class and XI IPS 2 as control class. The researchers applied Observe and Remember Game to treat the students to investigate the effectiveness of the game to students' vocabulary mastery. After administering both pretest and posttest, the writers analyzed the output data by using a statistical machine (SPSS) 21.

\section{RESULT AND DISCUSSION}

The study investigated whether or not Observe and Remember Game was effective to promote students' vocabulary at SMA Muhammadiyah. After giving the instruments to the respondents, the writers measured the validity of the instruments to have valid test items. After getting the validity, the writers then measured the reliability of instruments. In doing the calculation of validity and reliability of the instruments, SPSS 21 was applied.

Table 1 Reliability Statistics

\begin{tabular}{c|c}
\hline Cronbach's Alpha & N of Items \\
\hline .896 & 24 \\
\hline
\end{tabular}


Based on the computing of the SPSS program, it was found that Cronbach's Alpha was 0.896 . It meant the value of Cronbach Alpha is higher than the $r_{\text {table }}$ $(0.896>0.396)$. It can be concluded that the instrument of the test was reliable.

After having the validity and the reliability of the test items, the researchers gave a posttest to the experimental class and control class, then they applied the treatment using Observe and Remember Game.

The result of minimum and maximum scores of pretest and posttest of the experimental class and control class can be seen as follows.
Table 2

Result of Pretestand Posttest of Experimental Class and Control Class

\begin{tabular}{cccc}
\hline Test & $\mathbf{N}$ & Minimum & Maximum \\
\hline $\begin{array}{c}\text { Pretest of } \\
\text { Experimental } \\
\text { Class }\end{array}$ & 33 & 35.00 & $\mathbf{7 5 . 0 0}$ \\
Posttest of & 33 & 30.00 & 85.00 \\
$\begin{array}{c}\text { Experimental } \\
\quad \text { Class }\end{array}$ & & & \\
Pretest of Control & 33 & 30.00 & 60.00 \\
$\quad \begin{array}{c}\text { Class } \\
\text { Posttest of }\end{array}$ & 33 & 30.00 & 80.00 \\
Control Class & & & \\
\hline
\end{tabular}

Table 2 showed that the minimum score of the experimental class before treatment was 35 , the maximum score was 35 , and the minimum score of the control class before treatment was 30 and the maximum score was 60 . After the implementation of the Observe and Remember Game, researchers found that the minimum score of the experimental class was 30 and the maximum score was 85 , then the minimum score of the control class was 30 while the maximum score was 80 . The results showed that the maximum and minimum scores of 
posttest in experimental class and control class were higher than pretest scores but the value of the experimental class was higher than the control class.

Table 3

The Mean Scores of PretestGroup Statistics

\begin{tabular}{cccc}
\hline Group & N & Mean & $\begin{array}{c}\text { Std. } \\
\text { Deviation }\end{array}$ \\
\hline $\begin{array}{c}\text { Score of } \\
\text { Experimental } \\
\text { Class }\end{array}$ & 28 & 49,82 & 8,658 \\
$\begin{array}{c}\text { Score of Control } \\
\text { Class }\end{array}$ & 27 & 50,92 & 7,725 \\
\hline
\end{tabular}

Table 4

The Mean Score of Posttest Group Statistics

\begin{tabular}{cccc}
\hline Group & N & Mean & $\begin{array}{c}\text { Std. } \\
\text { Deviation }\end{array}$ \\
\hline $\begin{array}{c}\text { Score of } \\
\text { Experimental } \\
\quad \text { Class }\end{array}$ & 26 & 68,46 & 12,228 \\
$\begin{array}{c}\text { Score of Control } \\
\text { Class }\end{array}$ & 25 & 56,60 & 15256 \\
\hline
\end{tabular}

Based on the computing SPSS program, it was found the mean of the pretest (the analysis before treatment) in the experimental class was 49.82 , and the control class was 50.92. While the mean of posttest (the analysis after treatment) in the experimental class was 68.46 and in the control class was 56.60. It was told that mean of the posttest in the experimental class or control class was higher than the pretest, but the mean of posttest in the experimental class was higher than the control class.

After getting the scores of the students on pretest and posttest, the data were statistically computed to find $t_{\text {obtained }}$ than compare with $t_{\text {table. }}$ Table 5 presents the result of the computation of an independent sample test.

Table 5

Pretest Independent sample t-test

\begin{tabular}{|c|c|c|c|c|c|c|}
\hline \multirow{4}{*}{$\begin{array}{l}\text { Sco } \\
\text { re }\end{array}$} & & \multicolumn{2}{|c|}{$\begin{array}{l}\text { Levene's } \\
\text { Test for } \\
\text { Equality of } \\
\text { Variances }\end{array}$} & \multicolumn{3}{|c|}{$\begin{array}{c}\text { t-test for Equality of } \\
\text { Means }\end{array}$} \\
\hline & & $\mathbf{F}$ & Sig. & $\mathbf{t}$ & Df & $\begin{array}{l}\text { Sig. (2- } \\
\text { tailed) }\end{array}$ \\
\hline & $\begin{array}{c}\text { Equal } \\
\text { variance } \\
\mathrm{s} \\
\text { assumed }\end{array}$ & ,007 & ,934 & -499 & 53 & ,620 \\
\hline & $\begin{array}{l}\text { Equal } \\
\text { variances } \\
\text { ot assumed }\end{array}$ & & & , & $\begin{array}{c}52,6 \\
91\end{array}$ & 619 \\
\hline
\end{tabular}


Table 6

Posttest Independent Sample t-test

Levene's t-test for Equality of

Test for Means

Equality of

\begin{tabular}{lllll}
\multicolumn{2}{l}{ Variances } \\
\hline F Sig. & t & Df & Sig.
\end{tabular}

(2-

\begin{tabular}{ccccccc}
\hline Score & Equal variances & 4,3 &, 043 & 3,070 & 49 &, 003 \\
& assumed & 15 & & & & \\
& $\begin{array}{c}\text { Equal Variances } \\
\text { not assumed }\end{array}$ & & & 3,056 & 45,970 &, 004 \\
\hline
\end{tabular}

From the table above, the writers got the calculation of independent sample tests in pretest and posttest. In the pretest, the df was $53(\mathrm{df}=\mathrm{n}-\mathrm{k})$ and it was found that the value was sig. $0.934>0.05$ in Levene's test for equality of variances, which meant that data were homogeneous. Then it was found that $t_{\text {obtained }}$ was 0.499 , which meant that it was lower than $t_{\text {table }}$ (2.005). It can be summarized that there was no difference between the experimental class and the control class. The writers found that the value was significant at point 0.620 . It was higher than 0.05 , which meant there was no difference between the experimental class and the control class.

Besides, the result of the posttest showed that df of independent sample test was 49 (df $=\mathrm{n}-\mathrm{k})$ at significant level 0.043 or less than 0.05 in Levene's test which meant that the data were not homogeneous. Therefore, the writers took the value of equal variances not assumed, it was found that $t_{\text {obtained }}$ was 3.056. It meant that $t_{\text {obtained }}$ was (3.056) higher than $t_{\text {table }}$ (2.009) which indicated that there was a difference between experimental class and control class. The writers also found that the value of sig. (2tailed) was $0.004<0.05$, which 
meant there was a difference between the experimental and control classes.

The results of the data showed that the average pretest (before treatment) score in the experimental class was 49.82 , and the control class was 50,92. While the mean of the posttest (after treatment) in the experimental class was 68.46 and in the control class was 56.60 . It indicated that mean of the posttest in the experimental class or control class was higher than pretest, but the mean of the posttest in experimental class was higher than control class.

After getting students' scores on pretest and posttest, the data were statistically computed to find $t_{\text {obtained }}$ than compare with $t_{\text {table. }}$. The following table presents the result of the computation of an independent sample test.

\section{CONCLUSION}

The result of pretest and posttest showed that the mean scores of the students taught by using Observe and Remember Game increased about $18.64 \%$ from 49.82 to 68.46. It could be stated that Observe and Remember Game was effective to students' vocabulary mastery.

Therefore, Observe and Remember Game was good in promoting vocabulary teaching at the eleventh students of Senior High School. The claass atmosphere during the implementation of Observe and Remember Game enabled the students to memorize English 
vocabulary which was very

important in learning English.

\section{REFERENCES}

Astutik, Y. P. (2019). The influence of using flipbook media (Printed Vs. Displayed) to students reading comprehension achievement at STIT. M. Berau. in UNNES International Conference on English Language Teaching, Literature, and Translation (ELTLT 2018). Atlantis Press.

Brown, H. D. (2000). Principles of language learning and teaching $\left(2^{\text {nd }}\right.$ Ed). New York: Addison Wesley Longman, Inc.

Harmer, J. (1995). The practice of English language teaching. New York: Longman.

Hutcison. (2004). Old English literature. London: Oxford University Press.

Milarisa, S. (2018). The effect of using role plays technique among accounting students' speaking achievement at STIE Muhammadiyah Berau. English Community Journal, 2(1), 183193.

Muijs, D. (2004). During quantitative research in education with SPSS. London: Sage Publication Ltd.
Neuman, S. B., \& Dwyer, J. (2009). Missing in action vocabulary instruction in pre-k. The Reading Teacher, 62, 384-392.

Nordquist, R . (2006) Language: Glossary of grammatical and rethorical terms. Retrieved from http://grammar.about.com/od/gr ammarfaq/f/whatislang.htm. 